\title{
Z prawnej problematyki wspólnot gruntowych
}

1. Wspólnoty gruntowe są sposobem gospodarowania na gruntach rolnych, leśnych oraz obszarach wodnych. Stanowią pozostałość dawnych nadań na wspólną własność w wyniku uwłaszczenia oraz nadań tytułem odszkodowania za zniesione służebności ${ }^{2}$. W obowiązujących ramach prawnych wspólnoty gruntowe funkcjonują, z drobnymi modyfikacjami, od prawie pięćdziesięciu lat.

Ustawodawca, uchwalając ustawę z 29 czerwca 1963 r. o zagospodarowaniu wspólnot gruntowych, zakładał, że wspólnoty te będą służyły gospodarczemu współdziałaniu w rolnictwie ${ }^{3}$. W szczególności miały być jedną z organizacyjnoprawnych form gospodarki rolnej.

Obecnie obszar zajęty przez wspólnoty gruntowe przekracza 100 tys. ha, co stanowi około 6,25\% całkowitej powierzchni gruntów rolnych w kraju. Ich liczba jest szacowana na ponad 5 tys., ale tylko $20 \% \mathrm{z}$ nich funkcjonuje zgodnie z przepisami ustawy ${ }^{4}$. Wspólnoty te nie zawsze są właściwie prowadzone od strony organizacyjnej oraz prawnej, i co za tym idzie zarejestrowane. Jedynym źródłem informacji na ich temat jest ewidencja gruntów, gdyż dla wspólnot nie są prowadzone księgi wieczyste (art. 11 ustawy). W konsekwencji niniejsze rozważania powinny pozwolić na wskazanie najbardziej pożądanego przez uczestników wspólnot, jak i państwa kierunku ich przeobrażeń.

$\mathrm{Na}$ tle funkcjonowania wspólnot gruntowych występuje wiele problemów. Przede wszystkim, co znajduje wyraz w literaturze, należy zastanowić się, czy przystają do obecnych warunków gospodarczych ${ }^{5}$. Dlatego często pojawia się pytanie, czy wspólnoty gruntowe mają jeszcze rację bytu? ${ }^{6}$ Zauważył to także ustawodawca, który przygotował projekt zmiany ustawy.

\footnotetext{
Uniwersytet Przyrodniczy w Poznaniu.

J. Selwa, A. Stelmachowski, Prawo rolne, Warszawa 1970, s. 244 i n.

Dz.U. Nr 28, poz. 169 z późn. zm. (dalej: ustawa).

Zob. Informacja o wynikach kontroli aktualizacji stanu faktycznego i prawnego nieruchomości przez organy gospodarujące mieniem stanowiącym zasób nieruchomości Skarbu Państwa, gminny zasób nieruchomości i mienie gminne, Najwyższa Izba Kontroli Warszawa 2009, nr 5, s. 44 i n.

5 R. Szarek, Wspólnoty gruntowe - czy maja jeszcze rację bytu, „Finanse Komunalne” 2008, nr 10, s. 34-47.
}

$6 \quad$ Ibidem, s. 34-47. 
Celem niniejszego artykułu jest udzielenie odpowiedzi na pytanie, na ile przedstawiona propozycja legislacyjna rozwiązuje istniejące problemy wspólnot gruntowych. Ustawodawca rozważa kilka kierunków oraz rozwiązań, począwszy od całkowitej likwidacji wspólnot, poprzez ich zamianę we współwłasność. Z uwagi na to, rozważania będą dotyczyły zagadnień organizacji i funkcjonowania wspólnot gruntowych w obecnych, jak i proponowanych nowych warunkach legislacyjnych.

Wzrost zainteresowania wspólnotami gruntowymi wynika z wielu względów. Jednym z nich jest konieczność uregulowania stanu prawnego gruntów niezbędnych do tworzenia infrastruktury technicznej obszarów wiejskich i miejskich. Ma to związek z szeroko rozumianą komunalizacją mienia ogólnonarodowego ${ }^{7}$. Na tym tle pojawiło się wiele wątpliwości co do tego, czyją własnością są wspólnoty oraz kto faktycznie może nimi dysponować? Ponadto dużo kontrowersji budzi charakter prawny obciążeń na nieruchomościach będących w ich władaniu.

Na gruntach wchodzących w skład wspólnot bardzo często nie jest prowadzona ani produkcji rolnicza, ani leśna. Powodem tego jest często słaba jakość gleb, uniemożliwiająca pozyskiwanie odpowiednich, racjonalnych plonów. Wiele z tych gruntów mogłoby być przeznaczonych np. pod zabudowę, na lokalizację wysypiska śmieci, oczyszczalni ścieków, obiektów infrastruktury społecznej bądź na inne cele służące zadaniom własnym gminy.

Punktem wyjścia podejmowanej w artykule problematyki badawczej będzie przedstawienie funkcjonowania i organizacji wspólnot gruntowych w prawie polskim. Rozważania dotyczą w szczególności oddziaływania nań podstawowych instrumentów prawnych pod kątem zachodzących przemian społeczno-gospodarczych w kraju oraz zmiany legislacji w tym zakresie.

2. Jak zaznaczono na wstępie, podstawowym aktem prawnym regulującym funkcjonowanie wspólnot gruntowych jest ustawa z 29 czerwca 1963 r. o zagospodarowaniu wspólnot gruntowych ${ }^{8}$. Jej uchwalenie było próbą unifikacji na terenie całego kraju rozwiązań prawnych w odniesieniu do funkcjonowania omawianej instytucji prawnej. Ustawa ta określiła zakres przedmiotowy i podmiotowy wspólnot gruntowych oraz zagadnienia związane $\mathrm{z}$ ich zagospodarowaniem i rozporządzaniem.

W ustawie zabrakło sformułowania legalnej definicji wspólnoty gruntowej. Ustawodawca w art. 1 ust. 1 ustawy wymienił jedynie rodzaje nieruchomości, które ją tworzą i mogą wchodzić w jej skład ${ }^{9}$. Zagospodarowaniu w trybie i na zasa-

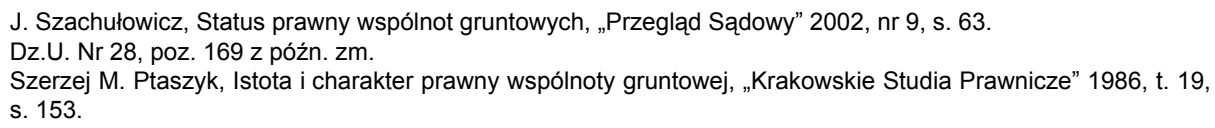


dach określonych w ustawie podlegały w szczególności grunty stanowiące mienie gromadzkie w rozumieniu przepisów o zarządzie takim mieniem, jeżeli przed dniem wejścia w życie tej ustawy były faktycznie użytkowane wspólnie przez mieszkańców wsi (art. 1 ust. 2). Wyjątkiem było tu mienie gromadzkie położone na terenach miast i osiedli (art. 1 ust. 3 ustawy). Ponadto do wspólnot gruntowych nie zostały zaliczone nieruchomości lub ich części określone w art. 1 ust. 1, jeżeli przed dniem wejścia w życie ustawy zostały prawnie lub faktycznie przekazane na cele publiczne lub społeczne albo też do końca 1962 r., a gdy chodzi o lasy i grunty leśne - do dnia 30 września 1960 r. zostały podzielone na działki indywidualne pomiędzy współuprawnionych bądź uległy zasiedzeniu.

Uczestnikami wspólnoty mogły zostać osoby fizyczne lub prawne posiadające gospodarstwo rolne, jeżeli w ciągu roku przed wejściem w życie ustawy faktycznie korzystały z tej wspólnoty (art. 6 ust. 1 ustawy). Zatem nie miał uprawnień do udziału we wspólnocie rolnik, niekorzystający z jej gruntów, jak również osoba niebędąca rolnikiem, a z nich korzystająca ${ }^{10}$.

Uprawnienia we wspólnocie i udziały w niej poszczególnych rolników zostały określone ex lege niezależnie od tego, czy osobom tym przysługiwały wcześniej przywileje rzeczowe do gruntów wspólnoty ${ }^{11}$. Natomiast gdy przedmiotem wspólnoty były lasy, grunty leśne lub nieużytki przeznaczone pod zalesienie, uprawnionymi do udziału w niej były osoby fizyczne lub prawne zamieszkujące lub mające siedzibę na terenie miejscowości, w której znajdowały się grunty stanowiące wspólnotę, lub osoby zamieszkujące na terenie innej miejscowości, a prowadzące gospodarstwo rolne, chyba że w okresie 5 lat przed wejściem w życie ustawy osoby te faktycznie ze wspólnoty nie korzystały (art. 6 ust. 2 ustawy). Uprawniona do udziału we wspólnocie mogła być zatem grupa mieszkańców jednej albo kilku wsi lub nawet całej gminy (gromady), o ile spełniała wymagania ustawowe.

Udziały poszczególnych uprawionych we wspólnocie gruntowej, zgodnie z art. 9 ust. 1, muszą być określane w częściach ułamkowych. Ich wielkość ustala się w ten sposób, że połowę wspólnoty dzieli się pomiędzy uprawnionych (art. 6 ust. 1) w równych częściach, drugą zaś połowę - proporcjonalnie do obszarów gruntów posiadanych przez każdego z nich, a położonych na obszarze tej samej lub graniczącej z nią gminy. Natomiast wielkość udziałów w przypadku lasów, gruntów leśnych albo nieużytków przeznaczonych do zalesienia ustala się na podstawie dokumentów, a w razie ich braku - według stanu faktycznego.

10 Tak np. R. Szarek, Wspólnoty gruntowe..., s. 37; wyrok NSA w Białymstoku z 18 maja 1995 r. SA/Bk 201/94, „Monitor Prawniczy” 1996, nr 7, s. 264.

11 Pisze o tym J. Szachułowicz, Zniesienie współwłasności i podział wspólnot gruntowych w postępowaniu scaleniowym, „Palestra” 1984, nr 9, s. 27. 
Podmiotem uprawnionym do ustalenia zakresu przedmiotowego, jak i podmiotowego wspólnot gruntowych były pierwotnie właściwe do spraw rolnych i leśnych organy prezydiów powiatowych rad narodowych, a po nowelizacji ustawy w $1990 \mathrm{r}$. jest nim starosta ${ }^{12}$. Do jego obowiązków należy sporządzenie wykazu uprawnionych do udziału we wspólnocie gruntowej oraz wykazu obszarów gospodarstw przez nich posiadanych i wielkość przysługujących im udziałów we wspólnocie, a następnie wydanie w tej sprawie decyzji administracyjnej (art. 8 ust. 2). Decyzja ta ma jedynie charakter deklaratoryjny. Wydając ją, starosta nie tworzy nowego stanu prawnego, lecz jedynie stwierdza już istniejący. Przy czym, nieruchomości nieobjęte decyzją, nie powinny być traktowane za wspólnoty ${ }^{13}$.

Zgodnie z rozwiązaniem przyjętym przez ustawodawcę wykazy, o których mowa, miały być sporządzone w terminie 1 roku od dnia wejścia w życie ustawy. Z kolei zakwalifikowanie nieruchomości do wspólnot nastąpiło z mocy ustawy $\mathrm{z}$ dniem jej wejścia w życie.

Warto w tym miejscu dodać, że uczestnik wspólnoty ex lege nabył uprawnienie do udziału we wspólnocie, polegające na możliwości korzystania z nieruchomości zgodnie z jej przeznaczeniem. Przykładowo sposobem używania gruntów należących do wspólnoty jest pobieranie pożytków z lasów oraz stawów, wypasanie zwierząt gospodarskich, zbiór siana etc.

Stosowanie przepisów omawianej ustawy rodzi obecnie wiele trudnych do usunięcia problemów natury praktycznej, proceduralnej oraz społecznej. Przede wszystkim niezmiernie skomplikowanym zadaniem jest zarówno ustalenie listy osób uprawnionych do udziału we wspólnotach gruntowych, jak i określenie pochodzenia gruntów wspólnie użytkowanych. Chodzi tu o ich zaliczenie albo do wspólnoty, albo do mienia gromadzkiego ${ }^{14}$. W wielu przypadkach, z uwagi na upływ czasu, nie można już w ogóle mówić o gruntach wspólnoty, tylko o gruntach indywidualnych jej uczestników, którzy na przestrzeni lat zdążyli je zasiedzieć ${ }^{15}$. Zatem pojawia się kolejne pytanie, czy skoro nie wiadomo które podmioty uczestniczą we wspólnocie, to czy w ogóle taka wspólnota powstała?

Kolejnym problemem w regulacji wspólnot jest okoliczność, że wskazanie osób uprawnionych do udziału w niej oraz wielkości przypadających im udziałów, jak również ustalenie nieruchomości wchodzących w skład wspólnoty następuje w drodze administracyjnej. Sprawy te nie podlegają więc kognicji sądów powszechnych,

Art. 1 ustawy z dnia 17 maja 1990 r. o podziale zadań i kompetencji określonych w ustawach szczególnych pomiędzy organy gminy a organy administracji rządowej oraz o zmianie niektórych ustaw, Dz.U. Nr 34, poz. 198. S. Rudnicki, Własność nieruchomości, Warszawa 2008, s. 31

14 Założenia do projektu ustawy o zagospodarowaniu wspólnot gruntowych, Ministerstwo Rolnictwa i Rozwoju Wsi, Warszawa październik 2010 r., s. 5.

15 M. Ptaszyk, Istota..., s. 161; R. Szarek, Glosa do postanowienia SN z dnia 24 października 2001 r. SA/III CKN 430/2000, Lex nr 40457. 
tymczasem w polskim systemie prawnym jest zasadą, że sprawy ze stosunków z zakresu prawa cywilnego, $w$ tym rzeczowego, rozpatrywane są przez sądy powszechne. Trudno wskazać przekonujące argumenty za właściwością tylko organów administracji i sądów administracyjnych w sprawach wspólnoty. Wprost przeciwnie, prawa majątkowe udziałowców wspólnoty gruntowej byłyby bardziej chronione w postępowaniu przed sądem powszechnym.

3. Omawiana ustawa określa zasady zagospodarowania wspólnot gruntowych, w tym gruntów użytkowanych rolniczo oraz nadających się do zagospodarowania rolniczego (art. 13 ust. 1 ustawy). W odniesieniu do lasów, gruntów leśnych i nieużytków przeznaczonych do zalesienia oraz obszarów wodnych i gruntów kopalnych (np. żwirów, piasków, gliny, torfu) pozwala na ich zagospodarowanie zgodnie z obowiązującymi w tym zakresie przepisami szczególnymi. Przykładem jest ustawa dnia 28 września $1991 \mathrm{r}$. o lasach ${ }^{16}$. Dopiero w ich braku ustawodawca zezwala na gospodarowanie odpowiadające charakterowi tych użytków ${ }^{17}$.

Zgodnie z art. 14 ustawy osoby uprawnione do udziału we wspólnocie gruntowej powinny utworzyć spółkę do sprawowania zarządu nad nią i do właściwego zagospodarowania gruntów wchodzących w jej skład. Jest to warunek sine qua non w zarządzaniu wspólnotą, co podkreśla Z. Truszkiewicz. Ustawodawca tym samym wyklucza powołanie jakiegokolwiek innego podmiotu ${ }^{18}$. Ustanowienie spółki następuje w drodze uchwały powziętej większością głosów uprawnionych do udziału we wspólnocie przy obecności przynajmniej ich połowy. Należy podkreślić, że jeżeli w skład wspólnoty wchodzą również inne grunty, w tym lasy, grunty leśne lub nieużytki przeznaczone do zalesienia, to do ich zagospodarowania może być utworzona odrębna spółka. Jej członkami mogą być osoby uprawnione do udziału we wspólnocie gruntowej oraz posiadacze gruntów przyległych do wspólnoty gruntowej na warunkach określonych w statucie. Przy podejmowaniu uchwały na zebraniach członków spółki każdy członek ma prawo tylko do jednego głosu bez względu na wielkość jego udziału w tej wspólnocie (art. 19 ustawy).

Spółka działa na podstawie statutu, który zatwierdza właściwy wójt (burmistrz, prezydent miasta). Jeżeli jednak uprawnieni do udziału we wspólnocie gruntowej, zgodnie z art. 25 ustawy, w terminie trzech miesięcy od dnia ustalenia wykazu uprawnionych nie przedstawią do zatwierdzenia statutu spółki, organ ten tworzy tzw. spółkę przymusową. Odpowiednio nadaje jej statut oraz wyznacza organy spółki spośród osób uprawnionych do udziału we wspólnocie gruntowej ${ }^{19}$.

16 Tekst. jedn. Dz.U. z 2011 r., Nr 12, poz. 59.

17 Pisze na ten temat W. Pawlak, Glosa do wyroku NSA, OZ Katowice z 20 grudnia 1994 r. SA/Ka 125/94, „Samorząd Terytorialny" 1997, nr 5, s. 71 i n.

18 Z. Truszkiewicz, Orzecznictwo Sądu Najwyższego w sprawach dotyczących stosunków rolnych, „Przegląd Prawa Rolnego" 2010, nr 1, s. 242.

19 Zob. wyrok WSA w Warszawie z 29 lipca 2009 r., SA/Wa 501/09, Lex nr 553386. 
Z chwilą zatwierdzenia statutu spółka nabywa osobowość prawną. Jak zauważa J. Szachułowicz, nie ma ona jednak sprecyzowanego charakteru prawnego ${ }^{20}$. Powstaje w oparciu o prawo administracyjne, a jej udziałowcami mogą być jedynie osoby legitymujące się statusem rolnika prowadzącego gospodarstwo rolne ${ }^{21}$. Spółka wykonuje zadania użyteczności publicznej, a jej działalność nie jest nastawiona na osiągnięcie zysku. Wypracowane przez nią dochody są obowiązkowo przeznaczane na doskonalenie jej funkcjonowania. W toku wykonywania swej działalności spółka jest uprawniona do wznoszenia i utrzymywania na wspólnocie gruntowej urządzeń potrzebnych dla osiągnięcia jej celów. Za wszelkie zobowiązania spółka odpowiada całym swoim majątkiem. Odpowiedzialność jej członków sięga wysokości wartości ich udziałów we wspólnocie.

Działalność spółki podlega kontroli. Wykonuje ją właściwy wójt (burmistrz, prezydent miasta), który jest zobowiązany do przyjmowania i zatwierdzenia w terminie oznaczonym w statucie spółki planu zagospodarowania oraz regulaminu użytkowania gruntów i urządzeń spółki. Tym samym jest on uprawniony do wprowadzenia we wskazanych powyżej dokumentach zmian i uzupełnień uzasadnionych względami gospodarczymi. Do zakresu działania ogólnego zebrania członków spółki, jako jej organu, należy między innymi podejmowanie uchwał w sprawie zbycia, zamiany oraz przeznaczenia na cele publiczne lub społeczne wspólnot lub ich części. Czynności te wymagają, pod rygorem nieważności, zgody wójta.

Powołana spółka do zagospodarowania wspólnot gruntowych może być wpisana do ewidencji producentów i tym samym może ubiegać się o otrzymanie dopłat bezpośrednich ${ }^{22}$. Warto w tym miejscu zaznaczyć, że jak zauważył sąd w wyroku z 14 lutego 2007 r., wspólnoty gruntowe mogą być objęte omawianym wsparciem, o ile spełniona jest przesłanka dotycząca powierzchni działek rolnych oraz ich utrzymywania w dobrej kulturze rolnej, przy zachowaniu wymogów środowiska ${ }^{23}$. Jednakże sami uczestnicy wspólnoty nie mają uprawnień do występowania w jej imieniu o ich otrzymanie. Mogą to czynić jedynie poprzez spółkę, która de iure została powołana do wznoszenia i utrzymywania na gruntach urządzeń potrzebnych dla osiągnięcia jej celów. Kompetencje przyznane spółkom przez ustawę wyłączają ich indywidualne działania. Odpowiednio nie uczestnicy wspólnoty, ale spółka jako osoba prawna jest uprawniona do podejmowania przed sądem czynności zarówno cywilnoprawnych, jak i procesowych.

Gdy chodzi o rozporządzanie wspólnotami gruntowymi, to zgodnie z art. 26 ustawy zbycie, zamiana, jak również przeznaczenie na cele publiczne lub społecz-

20 J. Szachułowicz, Spółki grup producentów rolnych spółkami użyteczności publicznej, „Studia luridica Agraria” 2005, t. 5, s. 203.

21 J. Szachułowicz, Spółki prawa administracyjnego, „Przegląd Sądowy” 2004, nr 2, s. 4.

22 Ibidem, s. 160.

23 WSA w Krakowie, III SA/Kr 914/05, Lex nr 534605. 
ne wspólnot gruntowych lub ich części oraz zaciąganie pożyczek pieniężnych przez spółkę może nastąpić tylko za zgodą właściwego wójta (burmistrza, prezydenta miasta). Należy podkreślić, że w razie sprzedaży nieruchomości stanowiącej wspólnotę gruntową gminie przysługuje prawo pierwokupu. Zasada ta nie ma zastosowania w razie zbycia wspólnoty gruntowej na rzecz państwa, jak również w razie zamiany gruntów wchodzących w skład wspólnoty na grunty państwowe. Ponadto prawa pierwokupu się nie stosuje do tej części gruntów wchodzących w skład wspólnoty, która została wyznaczona na cele budowlane na podstawie przepisów o terenach budowlanych na obszarach wsi bądź w miejscowym planie zagospodarowania przestrzennego. Prawo pierwokupu nie obejmuje także sprzedaży udziału we wspólnocie gruntowej. Trzeba zaznaczyć, że zgoda na dokonanie sprzedaży nie jest jednoznaczna ze zrzeczeniem się prawa pierwokupu przez gminę ${ }^{24}$. Niedopuszczalny jest także podział wspólnoty gruntowej pomiędzy uprawnionych, za wyjątkiem objęcia gruntów scaleniem, i to za zgodą większości uprawnionych do udziału w niej.

Ustawodawca ogranicza obrót gruntami należącymi do wspólnoty. Otóż, udział we wspólnocie gruntowej może być zbyty wyłącznie w całości i tylko na rzecz osoby posiadającej już udział w tej wspólnocie oraz na rzecz osób posiadających gospodarstwa rolne w tej samej wsi lub we wsiach przylegających do wspólnoty. Ostatni warunek ma służyć utrzymaniu stanu, w którym osobami uprawnionymi do udziałów są tylko i wyłącznie osoby prowadzące gospodarstwo rolne. Ponadto ustawodawca nie przewiduje możliwości nieodpłatnego przenoszenia własności nieruchomości gruntowej na rzecz osoby fizycznej ${ }^{25}$. Zbycie udziału we wspólnocie gruntowej następuje w formie ,,aktu sporządzonego na piśmie" i zatwierdzonego przez właściwego wójta (burmistrza, prezydenta miasta). W tym przypadku wymieniony organ niejako wydaje zezwolenie na dokonanie czynności prawnej i jest zobowiązany do zbadania wszystkich przesłanek określonych w ustawie i warunkujących skuteczność zbycia. Jego decyzja podlega zaskarżeniu do sądu administracyjnego.

Z kolei w razie zbycia wszystkich gruntów gospodarstwa rolnego przez uprawnionego do udziału we wspólnocie gruntowej udział w niej przechodzi na nabywcę tego gospodarstwa (art. 28 ust. 1). Takie rozwiązanie prawne znajduje także zastosowanie w sytuacji przejścia prawa do tego gospodarstwa na inne osoby w drodze uwłaszczenia z mocy prawa ${ }^{26}$. Bowiem zbycie gruntów nie ogranicza się tylko do przypadków umownego przeniesienia prawa. Z kolei w razie zbycia części gruntów udział we wspólnocie zachowuje dotychczasowy właściciel, chyba że na podstawie umowy odstapi swe uprawnienia nabywcy (art. 28 ust. 2). Jeżeli jednak zbywca pozostawia sobie obszar użytków rolnych nie większy niż 0,1 ha, udział ten przechodzi na nabywcę. Natomiast gdy gospodarstwo rolne, z którego posiadaniem był związa- 
ny udział we wspólnocie gruntowej, zostało podzielone na części w drodze działu spadku lub wyjścia ze współwłasności, udział we wspólnocie ulega podziałowi proporcjonalnie do obszaru tych części (art. 29).

Ponadto uprawnieni do udziału we wspólnocie gruntowej stanowiącej w całości lub w części lasy, grunty leśne lub nieużytki przeznaczone do zalesienia mogą się ich zrzec na rzecz państwa. Zrzeczenie następuje w trybie art. 27 ust. $2^{27}$.

Ustalone prawie pięćdziesiąt lat temu zasady zagospodarowania wspólnot nie przystają do współczesnych realiów gospodarczych, a przede wszystkim do zasad państwa prawa. Dotyczy to zwłaszcza sytuacji prawnej podmiotów, którym przysługują określone uprawnienia w ramach przynależności do wspólnoty. Nie ulega wątpliwości, iż prawa przysługujące udziałowcom wspólnot gruntowych mają określone znaczenie gospodarcze. Tymczasem nie istnieje żadna forma sądowej kontroli organów spółek do zagospodarowania wspólnot gruntowych.

W relacji spółka a grunt wspólnoty należy zauważyć, że ten ostatni nie stanowi jej majątku jako osoby prawnej ${ }^{28}$. Do jej spraw należy tylko zarządzanie wspólnotą. Swoistość uregulowania polega na dużej ingerencji organów administracji w kwestie powołania i zarządu spółki oraz sprawowania zarządu przez jej organ. Zatem należy mówić o jej specyficznym charakterze wynikającym z ustawy ${ }^{29}$.

Warto podkreślić, że spółki są formą przymusowej organizacji producentów rolnych będących uczestnikami wspólnoty gruntowej. Jak zauważa B. Jeżyńska, producenci rolni są pozbawieni możliwości podejmowania indywidualnych decyzji i działań na rzecz spółki ${ }^{30}$. To ona decyduje we wszelkich sprawach dotyczących zarówno jej bytu prawnego, jak i sposobu użytkowania gruntów wchodzących w jej skład.

Na obecny stan zagospodarowania wspólnot gruntowych składa się także indywidualny stosunek samych ich uczestników. Przede wszystkim wielu z nich nie widziało i nie widzi potrzeby stosowania przepisów omawianej ustawy. Osoby te najczęściej korzystają z nieruchomości w sposób ustalony zwyczajowo, a przyjęty w danej miejscowości. W wielu przypadkach przeszkodą w spełnieniu założeń ustawodawcy jest nieświadomość prawna oraz obawa przed koniecznością podejmowania działań administracyjno-organizacyjnych. Często uczestnicy nie utożsamiają się z osobami uprawnionymi do korzystania i pobierania pożytków z gruntów wspólnoty. Sytuacja ta zaczęła się stopniowo zmieniać wraz z pojawieniem się możliwości uzyskiwania wsparcia unijnego. Początkowo status prawny wspólnot gruntowych

27 Zob. nieobowiązujący już art. 179 kc.

28 B. Jeżyńska, Organizacja gospodarstwa rolnego jako spółki, (w:) Prawo rolne, pod red. A. Oleszki, Warszawa 2009, s. 183.

29 J. Szachułowicz, Zniesienie..., s. 27.

30 B. Jeżyńska, Organizacja..., s. 183. 
jako ich beneficjentów nie był jednoznaczny i nadal, jak podkreśla E. Kremer, nie ukształtowało się w tym względzie jednolite orzecznictwo ${ }^{31}$.

Niechęć do udziału w ramach wspólnoty wynika także z obciążeń podatkowych nakładanych na wspólnotę jako osobę prawną. Uczestnicy wolą swobodnie, choć w ograniczonym zakresie korzystać z gruntów, aniżeli podejmować decyzję o powołaniu spółki i tym samym odprowadzać wymagany podatek dochodowy. Z drugiej strony, do niewypełnienia wszystkich założeń ustawodawcy przyczyniły się zaniechania organów administracji, które rzadko kiedy same podejmowały inicjatywę uregulowania stanu prawnego wspólnot.

4. Funkcjonujące do dnia dzisiejszego wspólnoty gruntowe należy traktować jako pewien instrument polityki państwa, zmierzający do realizacji wskazanego w ustawie sposobu gospodarowania na gruntach wspólnych.

Jednakże ustawa ta przyczyniła się do powstania i przede wszystkim utrzymywania chaosu organizacyjno-prawnego w funkcjonowaniu wspólnot gruntowych. Analizując jej art. 1 ust. 1 pkt 1, można zauważyć pewną mozaikę stanów faktycznych i uprawnień: „nadane w wyniku uwłaszczenia włościan i mieszczan-rolników na wspólną własność, we wspólne posiadanie lub do wspólnego użytkowania ogółowi, pewnej grupie lub niektórym mieszkańcom jednej albo kilku wsi”. Mowa tu o własności oraz posiadaniu, które są stanem faktycznym podlegającym pewnej ochronie prawnej oraz o użytkowaniu, które jest ograniczonym prawem rzeczowym.

Warto podkreślić, że charakter prawny wspólnot gruntowych nigdy nie został sprecyzowany $^{32}$. Niemniej, jak zauważa S. Rudnicki, ustawodawca nadał im szczególną konstrukcję prawną odrębną od przepisów prawa cywilnego, mimo że wykazują one wiele cech typowych dla prawa rzeczowego ${ }^{33}$.

Wspólnota gruntowa od strony prawnej jest najbardziej zbliżona do współwłasności. Może ona być traktowana jako jej szczególny rodzaj, niepodlegający podziałowi, rządzący się własnymi zasadami (art. 5 ustawy). Współwłasność ta oparta jest na uprawnieniu przysługującym osobom fizycznym lub prawnym, posiadającym gospodarstwa rolne do udziału we wspólnocie gruntowej. Polega on na korzystaniu z należących do niej gruntów zgodnie z ich przeznaczeniem. Poszczególnym udziałowcom wspólnoty nie przysługują uprawnienia wynikające z przepisów Kodeksu cywilnego o współwłasności w takim zakresie, w jakim byłoby to sprzeczne z zasa-

31 E. Kremer, Wybrane zagadnienia z problematyki rozwoju obszarów wiejskich, płatności bezpośrednich w orzecznictwie sądów administracyjnych, „Studia luridica Agraria” 2009, nr 7, s. 156.

S. Rudnicki, Własność..., s. 29. 
dami wynikającymi z przepisów omawianej ustawy ${ }^{34}$. Warto podkreślić, że rozwiązania kodeksowe o charakterze lex specialis stosuje się tylko w zakresie nieuregulowanym ustawowo ${ }^{35}$.

W wyroku III SA/Wa 501/09 instytucja wspólnot gruntowych jest traktowana jako relikt uwłaszczenia włościan, wynikający ze zmian polityczno-własnościowych $^{36}$. Przy tym zmiany te zachodzą stale i z tego tytułu zarówno od strony prawnej, jak i organizacyjnej wspólnoty gruntowe nie wpisują się we współczesne realia. Ich byt prawny implikuje wiele problemów natury podmiotowej, przedmiotowej i organizacyjnej. Na taki stan rzeczy wpływ ma wiele czynników. Przede wszystkim w momencie wydzielania wspólnot gruntowych obowiązywała inna niż obecnie polityka rolna państwa. Zgodnie z nią wspólnoty były traktowane jako forma grupowej własności ziemi, której podstawowym celem było zapobieżenie rabunkowej, nieekonomicznej na tamte czasy gospodarce ${ }^{37}$. Jednym z założeń tzw. optymalnej polityki rolnej było wskazanie punktu równowagi między swobodnym obrotem ziemią a jej gospodarowaniem, przy jednoczesnym utrzymaniu maksymalnej inicjatyw produkcyjnej jej użytkowników, która de facto miała płynąć z ich poczucia własności.

W praktyce grunty przyznane niektórym wspólnotom dawno już zostały nieformalnie podzielone i są użytkowane indywidualnie. Ponadto wiele $\mathrm{z}$ nich charakteryzuje się słabą przydatnością rolniczą lub wadliwym ukształtowaniem rozłogu, co również jest istotnym mankamentem w ich właściwym, ekonomicznym wykorzystywaniu.

Powyższe problemy, w tym przede wszystkim konieczność uregulowania stanu prawnego nieruchomości, znalazły wyraz w projekcie nowelizowanej ustawy ${ }^{38}$.

Propozycja zawarta w projekcie przewiduje dwa rozwiązania prawne co do dalszego bytu wspólnot gruntowych. Pierwszym z nich jest przekształcenie wspólnot we współwłasność w rozumieniu art. 195 Kodeksu cywilnego ${ }^{39}$. Przekształcenie takie mogłoby dotyczyć tylko tych jednostek, w których znane są wielkości udziałów oraz dla których utworzono spółki do sprawowania zarządu. Miałoby ono nastąpić w drodze uchwały powziętej większością głosów uprawnionych do udziału we wspólnocie. Uchwała ta, sporządzona w formie aktu notarialnego, byłaby podstawą do ujawnienia współwłasności w ewidencji gruntów i budynków oraz w księdze

34 Uchwała SN z 9 grudnia 1969 r., III CZP 89/69, OSNC 1970, nr 10, poz. 173.

35 S. Rudnicki, Własność..., s. 29; G. Bieniek, S. Rudnicki, Nieruchomości. Problematyka prawna, Warszawa 2009, s. 1045 i n.

36 Wyrok WSA w Warszawie z 29 lipca 2009 r., SA/Wa 501/09, Lex nr 553386.

37 S. Ignar, Polityka agrarna. Podręcznik, Warszawa 1968, s. 193.

38 Prace nad projektem nowelizacji ustawy rozpoczęły się w 2008 r. Jej celem jest uregulowanie stanu prawnego nieruchomości, których ustalenie na podstawie obecnie obowiązujących przepisów o zagospodarowaniu wspólnot nie jest możliwe oraz dostosowanie niektórych rozwiązań prawnych do współczesnych realiów społecznogospodarczych. 
wieczystej. Należy zaznaczyć, że udział, jaki by przysługiwał każdemu ze współwłaścicieli, odpowiadałby wielkości udziału uprawniającego do korzystania ze wspólnoty gruntowej. Jednocześnie podjęcie takiej uchwały dawałoby możliwość i podstawę do rozwiązania oraz likwidacji spółki.

Drugim z proponowanych rozwiązań prawnych jest utrzymanie niektórych ze wspólnot gruntowych. Dotyczy to jednak tylko tych, które funkcjonują zgodnie z przepisami prawa i działają w oparciu o rachunek ekonomiczny. Będzie to dotyczyło tych wspólnot, w których do dnia wejścia w życie znowelizowanej ustawy znane są wielkości udziałów osób uprawnionych, a zarządzanie wspólnotą prowadzone jest przez spółkę. Tym samym będą one mogły gospodarować na dotychczasowych zasadach, jeżeli taka będzie wola samych uprawnionych ${ }^{40}$.

Ustawodawca zakłada, że uprawnionymi do udziału we wspólnocie będą osoby fizyczne lub prawne posiadające gospodarstwa rolne, jeżeli nieprzerwanie od 1 stycznia 2009 r. do dnia 31 grudnia 2011 r. faktycznie korzystały ze wspólnoty. Natomiast jeżeli wspólnotą objęte są lasy, grunty leśne albo nieużytki przeznaczone do zalesienia, to uprawnionymi do udziału we wspólnocie będą osoby fizyczne lub prawne zamieszkujące lub mające siedzibę na terenie miejscowości, w której znajdują się grunty wspólnoty, lub osoby zamieszkujące na terenie innej miejscowości, ale prowadzące gospodarstwo rolne. Nie dotyczy to jednak osób, które we wspominanym powyżej terminie faktycznie ze wspólnoty nie korzystały.

Duże znaczenie dla bytu prawnego wspólnot gruntowych ma propozycja uchylenia art. 11 ustawy, dotyczącego nieprowadzenia ksiąg wieczystych. Bowiem do dnia dzisiejszego jedynym rejestrem, w którym są ujawniane informacje dotyczące gruntów wspólnoty oraz spółki, jest ewidencja gruntów i budynków.

Proponowane przekształcenie wspólnot we współwłasność implikowałoby stworzenie dla tychże nieruchomości właściwego im rejestru wraz z ujawnieniem wszelkich obciążeń oraz prowadziłoby do jej zagospodarowania. Warto jeszcze podkreślić, że w oparciu o obecny stan prawny nie można powołać nowej wspólnoty. Ustawodawca przewiduje jedynie możliwość reaktywacji i ,uporządkowania” już kiedyś istniejących, co z uwagi na brak ksiąg wieczystych nie jest procesem łatwym $^{41}$.

Zatem pojawia się pytanie, co by mogło być przedmiotem wpisu do księgi wieczystej oraz jaki podmiot byłby w niej ujawniony. W tym przypadku należy wziąć pod uwagę okoliczności powstawania wspólnot gruntowych i odpowiednio zbadać stan sprzed pięćdziesięciu lat. Warto w tym miejscu zaakcentować, że istnieje wiele przypadków, w których w ogóle nie można ustalić liczby uczestników wspólnot. Są 
one potocznie określane mianem „ekwiwalentowych”. Ich uczestnicy w drodze losowania wyznaczają, kto będzie miał prawo w danym roku do udziału we wspólnocie i w jakim zakresie.

Jednocześnie ustawodawca przewiduje uchylenie art. 8 pkt 5 ustawy, zgodnie z którym ustalenie, które nieruchomości stanowią wspólnotę gruntową bądź mienie gromadzkie oraz ustalenie wykazów uprawnionych do udziału we wspólnocie, powinno być dokonane w terminie 1 roku od dnia wejścia w życie ustawy. Termin ten ma jedynie charakter instrukcyjny i nie ma przeciwwskazań, by spółka zwróciła się w każdej chwili do starosty o wydanie decyzji umożliwiającej dokonanie stosownych zmian w ewidencji ${ }^{42}$.

Ze względu na zawiłość omawianego procesu porząakowania wspólnot gruntowych ustawodawca zakłada, by w terminie 12 miesięcy od dnia wejścia w życie ustawy, właściwi starostowie dokonali ,przeglądu” nieruchomości stanowiących grunty wspólnotowe i grunty gromadzkie ${ }^{43}$. Jego konsekwencją ma być sporządzenie wykazu nieruchomości, w stosunku do których nie wydano dotychczas stosownych decyzji. W ich przypadku starostowie powinni wszcząć z urzędu postępowanie administracyjne mające na celu określenie, które nieruchomości stanowią wspólnoty gruntowe bądź mienie gromadzkie oraz ustalające wykaz osób należących do tej wspólnoty i ich udziały oraz wydanie odpowiednich decyzji administracyjnych.

Ustawodawca proponuje także wprowadzenie przepisu przejściowego, zgodnie z którym do postępowań mających na celu wydanie decyzji ustalających skład przedmiotowy i osobowy wspólnot, wszczętych i niezakończonych przed dniem wejścia w życie zaproponowanej zmiany art. 6, będą miały zastosowanie przepisy dotychczasowe. Jednakże gdy postępowanie to nie zakończy się ustaleniem wykazu uprawnionych, starosta będzie mógł wszcząć nowe.

W przypadku, gdy nie będzie możliwe ustalenie takiego wykazu, na staroście ciąży obowiązek złożenia w sądzie wniosku o stwierdzeniu nabycia nieruchomości przez Skarb Państwa. Nieruchomości, które staną się własnością Skarbu Państwa, będą mogły być przekazywane gminie na jej wniosek na cele związane z inwestycjami infrastrukturalnymi służącymi wykonywaniu zadań własnych.

Natomiast w sytuacji wspólnot, w których są sporządzone wykazy uprawnionych, ale w których uprawnieni nie zawiązali spółki i nie przedstawili wójtowi do zatwierdzenia statutu, wymagane będzie, aby stały się one z mocy prawa współwłasnością osób uprawnionych. 
Proponowane zmiany obejmują także zagadnienia związane z zagospodarowaniem wspólnot gruntowych. W tym zakresie ustawodawca przewiduje pewne modyfikacje w odniesieniu do ustroju spółek powoływanych do sprawowania zarządu nad wspólnotą gruntową. W pierwszej kolejności zmierza on, by należności spółek z tytułu nieuiszczonych w terminie opłat statutowych oraz opłat $\mathrm{z}$ tytułu kosztów zastępczego wykonania świadczeń przewidzianych w statucie mogły być dochodzone w postępowaniu upominawczym, bez względu na ich wysokość, a nie jak dotychczas w trybie egzekucji administracyjnej.

Projekt przewiduje także uzupełnienie art. 17 ustawy w zakresie statutu, który dodatkowo powinien określać przypadki wymagające zwołania zebrania członków spółki oraz warunki zaciągania zobowiązań i udzielania pełnomocnictw. Także odnosi się do formy zatwierdzania statutu przez wójta (burmistrza, prezydenta miasta) w drodze decyzji administracyjnej. Z kolei w obowiązującym stanie prawnym uchwała organu spółki jest niezaskarżalna. W praktyce obecność osób uprawnionych ogranicza się do udziału w obradach ogólnych zebrań członków wraz z prawem głosu oraz prawem wyboru do organów spółki. Ustawa nie przewiduje żadnej drogi odwoławczej. Ponadto nie zapewnia ona sądowej kontroli decyzji organów spółki w zakresie, w jakim rozstrzygają one o prawach i obowiązkach majątkowych. Zatem nowelizacja zmierza do tego, by każdy członek spółki mógł zaskarżyć uchwałę do sądu z tytułu jej niezgodności z przepisami prawa lub ze statutem. Powodem zaskarżenia może być naruszenie zasad właściwego zagospodarowania gruntów lub inne naruszenie interesów członka spółki. Powództwo będzie mogło być wytoczone przeciwko spółce w terminie 30 dni od dnia otrzymania informacji o uchwale, nie później jednak niż w terminie 6 miesięcy od dnia jej podjęcia. W zakresie rozporządzania wspólnotami, ustawodawca proponuje usunięcie ograniczeń dotyczących obrotu jej gruntami, które polegają na uzyskaniu zgody właściwego wójta.

5. Niniejsze rozważania prowadzą do stwierdzenia, że obowiązująca regulacja dotycząca wspólnot gruntowych nie została w pełni zrealizowana. Nic więc dziwnego, że Ministerstwo Rolnictwa i Rozwoju Wsi podjęło się próby jej nowelizacji.

Ze względu na uwarunkowania prawne i gospodarcze obowiązujące w okresie formułowania przepisów ustawy z dnia 29 czerwca 1963 r. o zagospodarowaniu wspólnot gruntowych wiele przepisów tej ustawy budzi obecnie kontrowersje i wymaga wprowadzenia zmian. Dlatego też z powyższych względów niezbędnym wydaje się w pierwszej kolejności uregulowanie stanu prawnego wspólnot. Takie zamierzenie przewiduje projekt ustawy.

$\mathrm{Z}$ uwagi na występowanie wielu dysproporcji w funkcjonowaniu wspólnot zasadna wydaje się być ich dywersyfikacja. Zarówno proponowane utrzymanie niektórych wspólnot, jak i przekształcenie pozostałych z nich we współwłasność daje szansę ich uczestnikom na dokonanie wyboru formy gospodarowania gruntami. 
Możliwość ta wydaje się być konieczną, bowiem na kształtowanie wspólnot gruntowych - jak zaznaczono we wstępie - obok omawianej ustawy (albo przede wszystkim) wpływ miały uwarunkowania historyczne. Wspólne wykorzystywanie gruntów rolnych i leśnych wpisuje się $\mathrm{w}$ tradycję polskiej wsi. $\mathrm{Z}$ tego powodu ich charakter jest bardzo zróżnicowany i należałoby, przy podejmowaniu decyzji o losie każdej ze wspólnot, rozpatrywać tę kwestię indywidualnie.

Proponowany proces przekształceń jest uzależniony od tego, czy są spełnione podstawowe przesłanki ustawowe, tj. czy jest ustalona liczba członków i ich udziały oraz powołana spółka. Swobodnego wyboru są jednak pozbawieni uczestnicy wspólnot, w których spółka nie została wyłoniona. Ich grunty z mocy prawa mają być przekształcone we współwłasność. Propozycja ta ma uzasadnienie praktyczne skoro przez tyle lat nie wyłoniono organu wspólnoty, zatem nie spełniono podstawowego warunku prawidłowego funkcjonowania wspólnoty.

Ustanowienie współwłasności gruntów wchodzących w skład wspólnoty zwalnia jej uczestników, jako współwłaścicieli, z konieczności ponoszenia kosztów związanych z funkcjonowaniem spółki. Jednocześnie pozwoli im to na dysponowanie gruntami, co de facto spowoduje wprowadzenie do obrotu sporego ich areału. Niemniej w ich przypadku powinien ulec ułatwieniu proces postępowania uwłaszczeniowego. Warto by też podjąć dyskusję nad tym, czy istnieje jakakolwiek inna forma wspólnego zarządzania tymi gruntami poza samą wspólnotą?

$\mathrm{W}$ projektowanym akcie prawnym zabrakło rozwiązania prawnego w stosunku do tych wspólnot, których grunty wcześniej zostały przeznaczone na realizację celów publicznych. Zatem, czy ich byli udziałowcy nabędą prawo do odszkodowania $\mathrm{z}$ tego tytułu?

W Polsce występują wspólnoty gruntowe, które nadążają za zmieniającą się sytuacją polityczno-gospodarczą, działają zgodnie z przepisami prawa i powinny one funkcjonować dalej. Przemawia za tym fakt, że na przestrzeni wielu lat ich uczestnicy ustalili zasady korzystania z gruntów, a dla niektórych wręcz są one niezbędne do funkcjonowania w ramach własnych gospodarstw rolnych. Tym samym ich pozostawienie wydaje się być uzasadnione, co również słusznie zauważył A. Stelmachowski ${ }^{44}$. Niemniej wiąże się to $\mathrm{z}$ koniecznością określenia właściwego sposobu zarządzania nimi, w tym poprzez spółki. W przypadku tych ostatnich proponowana zmiana art. 17 ustawy powoduje ich częściowe zbliżenie do spółek prawa handlowego.

W projekcie zabrakło uściślenia kwestii prowadzenia ksiąg wieczystych. Samo zniesienie zakazu z art. 11 ustawy wydaje się być niewystarczające. Mianowicie, 
w przypadku przekształcenia wspólnoty gruntowej we współwłasność założenie księgi i dokonanie odpowiednich wpisów nie budzi wątpliwości, natomiast w przypadku pozostawienia wspólnot gruntowych już tak. Nadal bowiem nie zostało ustalone, kto od strony podmiotowej powinien być w niej wpisany jako właściciel. Czy w tym przypadku należałoby traktować wspólnotę jako własność Skarbu Państwa, a ustanowione na niej obciążenia jako ograniczone prawa rzeczowe ${ }^{45}$ ? Trzeba w tym miejscu podkreślić, że nigdy zamiarem ustawodawcy nie było zagospodarowanie gruntów państwowych w oparciu o wspólnotę gruntową, a tylko w uzasadnionych przypadkach Skarb Państwa mógł te grunty nabyć lub stać się ich udziałowcem ${ }^{46}$.

Na koniec warto podkreślić, że wspólnoty gruntowe nie tylko występują w Polsce, ale i na terenie wielu państw świata. Przykładowo tzw. common land (albo commons) funkcjonują od wieków na terenie Wielkiej Brytanii, gdzie istnieje specjalnie powołany urząd, który nadzoruje ich zagospodarowanie ${ }^{47}$. Uprawnione do udziału w nich podmioty wykorzystują grunty wchodzące w ich skład do wypasu owiec i bydła, pozyskiwania torfu, drewna czy połowu ryb ${ }^{48}$. Innym przykładem może być ejido, które występuje w Meksyku ${ }^{49}$. Treść uprawnień i obowiązków z niego wynikających odpowiada zarówno rodzimym wspólnotom, jak i brytyjskim commons. Wspólne użytkowanie gruntów jest powszechnie stosowane także na terenach alpejskich w Szwajcarii, gdzie noszą one nazwę Allmende. Zatem jak widać, mimo, że rodzime wspólnoty gruntowe wydają się być przeżytkiem minionej epoki, to pełnią one w wielu przypadkach istotną rolę w szeroko rozumianej działalności rolniczej.

45 G. Bieniek, S. Rudnicki, Nieruchomości..., s. 1050.

$46 \quad$ Zob. art. 26 ust. 3 ustawy.

47 www.direct.gov.uk/en/HomeAndCommunity/Planning/LandAndPropertyDevelopment/DG_10026177, 30.12.2011 r.

48 Zob. np. Commons Act 2006, www.defra.gov.uk/rural/protected/commons, 30.12.2011. Podobne wspólnoty występują także w Indiach i Nepalu.

49 Zob. www.mexicolaw.com.mx/ejido.html, 30.12.2011. 


\section{Legal issues of joint land properties}

Key words: joint land property, partnership, agricultural holding

The joint land properties belong to the dwellers of a given commune. Their land covers almost 100 thousands ha. They have a long history, but from the legal side, they were established in 1963. Since then, the basis legislation has not change much, unlike the political, social and economic situation in Poland.

Nowadays, the joint land properties quit often are run against the law, many of them have not established the proper partnerships and do not act in required way. Thus the legislator has made an attempt to change such a situation.

The article attempts to analyze the suggested changes in the legislation. It considers both the proposal of their elimination and as well as their maintenance with some legal modifications. Those aspects are analyze from their historical, practical and legal points of view. 